Terakreditasi Sinta 3 | Volume 4 | Nomor 4 | Tahun 2021 | Halaman 515-528

P-ISSN 2615-725X | E-ISSN 2615-8655

http://diglosiaunmul.com/index.php/diglosia/article/view/273

\title{
Cerita Pangeran Kornel dalam Perspektif Sastra dan Sejarah
}

\section{The Story of Prince Kornel in Literary and Historical Perspective}

\author{
Danan Darajat $^{1, *}$, Dedi Koswara ${ }^{2}$, dan Retty Isnendes ${ }^{3}$ \\ ${ }^{1,2,3}$ Sekolah Pascasarjana, Universitas Pendidikan Indonesia \\ 1,* Corresponding email: danan.darajat@upi.edu \\ ${ }^{2}$ Email: dedi.koswara@upi.edu \\ ${ }^{3}$ Email: retty.isnendes@upi.edu
}

Received: 8 July 2021 Accepted: 15 September 2021 Published: 12 November 2021

\begin{abstract}
This article is motivated by ambiguity about a famous Cadas Pangeran road construction figure, Prince Surianagara Kusumahdinata or Prince Kornel. The approaches used in this article are descriptive and historical methods, literature review techniques, documentation studies, and interviews. The article aims to find out: (1) the character of Prince Kornel from a literary perspective; (2) the character of Prince Kornel from a historical perspective; (3) the synchronization of Prince Kornel's character in literature and history. The results show that the character of Prince Kornel in literature and history is not significantly different. The difference is that there is imagination in literature to build certain atmospheres that make the story more alive, and in history, it is based on existing historical facts. In addition, the character of Prince Kornel has a correlation viewed from matters relating to literature and history. The conclusion is that the story of Prince Kornel in literature is produced by historical events and the community's oral tradition about Prince Kornel that spread in Sumedang Regency. It can be said that the story of Prince Kornel from literary and historical perspectives is interconnected and influences each other.
\end{abstract}

Keywords: history, literature, Prince Kornel

\begin{abstract}
Abstrak: Penulisan artikel ini dilatarbelakangi oleh adanya keambiguan mengenai salah seorang bupati yang terkenal dalam proses pembuatan Jalan Cadas Pangeran, yaitu Pangeran Surianagara Kusumahdinata atau yang sering disebut Pangeran Kornel. Dengan menggunakan metode deskriptif dan historis (sejarah), teknik telaah pustaka, studi dokumentasi, dan wawancara, artikel ini ditulis untuk menjawab masalah mengenai: (1) tokoh Pangeran Kornel dalam perspektif sastra; (2) tokoh Pangeran Kornel dalam perspektif sejarah; dan (3) sinkronisasi tokoh Pangeran Kornel dalam sastra dan sejarah. Hasil penelitian menunjukkan bahwa tokoh Pangeran Kornel dalam sastra dan sejarah tidak jauh berbeda, hanya saja dalam sastra ditambahkan imajinasi untuk membangun suasana-suasana tertentu yang membuat cerita semakin hidup, sedangkan dalam sejarah benar-benar berdasarkan pada fakta sejarah yang ada. Selain itu, dari kedua hal yang berkaitan dengan sastra dan sejarah, tokoh Pangeran Kornel mempunyai keterkaitan. Kesimpulannya bahwa cerita Pangeran Kornel dalam sastra dihasilkan dari peristiwa sejarah dan juga tradisi lisan masyarakat tentang Pangeran Kornel yang berkembang di Kabupaten Sumedang. Maka dapat disebutkan bahwa cerita Pangeran Kornel dalam perspektif sastra dan sejarah saling berhubungan dan saling memengaruhi.
\end{abstract}

Kata kunci: Pangeran Kornel, sastra, sejarah

To cite this article:

Darajat, D., Koswara, D., \& Isnendes, R. (2021). Cerita Pangeran Kornel dalam Perspektif Sastra dan Sejarah. Diglosia: Jurnal Kajian Bahasa, Sastra, dan Pengajarannya, 4(4), 515-528. https://doi.org/10.30872/diglosia.v4i4.273 


\section{A. PENDAHULUAN}

Pangeran Kornel atau nama kecilnya Raden Jamu dan nama lengkapnya Pangeran Surianagara Kusumahdinata atau Raden Tumenggung Adipati Aria Surianagara, merupakan putra dari Adipati Surianagara, Bupati Sumedang tahun 1761-1765 (Lubis, dkk., 2008, hlm. 149). Dalam sastra maupun sejarah, nama Pangeran Kornel sering menjadi perbincangan hangat, sebagai contohnya terdapat karya sastra novel Pangéran Kornél karya R. Memed Sastrahadiprawira (terbitan Kiblat, 2014) dan juga novel Raden Jamu, Mutiara Menak Sumedang karya Tatang Sobana (terbitan Panca Utama Mandiri, 2006). Selain itu, nama Pangeran Kornel juga sering dibahas dalam buku-buku sejarah yang berkaitan dengan Kabupaten Sumedang, seperti dalam buku Rucatan Budaya Sumedang karya WD. Dharmawan Wangsapurwacaraka (1994), Sajarah Sumedang karya E. Kosmajadi (1994), dan Sejarah Sumedang dari Masa ke Masa karya Nina H. Lubis, dkk. (2008).

Banyaknya pembahasan yang berkaitan dengan Pangeran Kornel dalam karya sastra dan juga buku sejarah merupakan bukti bahwa nama tersebut sangat penting dalam perjalanan sejarah kebudayaan Sunda, terutama dalam proses pembuatan jalan bersejarah penghubung wilayah yang sekarang dikenal dengan sebutan Jalan Cadas Pangeran. Hal tersebut sejalan dengan yang dikemukakan oleh Nurlaela (2019) bahwa peristiwa Cadas Pangeran sangat penting bagi masyarakat Kabupaten Sumedang. Apalagi jika mengungkap tokoh dibalik pembuatannya, yaitu Pangeran Kusumahdinata. Mandela (2015, hlm. 52) menyebutkan bahwa Pangeran Kusumahdinata atau yang akrab disebut Pangeran Kornel merupakan sosok pemimpin yang bertanggungjawab. Selain itu, Kosmajadi (1994, hlm. 38) juga menegaskan bahwa Pangeran Kornel merupakan sosok bupati yang tidak bisa dilupakan, karena perjuangannya membela rakyat Sumedang di hadapan Jenderal Daendels. Kedua pendapat tersebut sejalan dengan pandangan Isnendes dan Firmansyah (2013, hlm. 90) yang menyebutkan bahwa tokoh Pangeran Kornel merupakan tokoh yang bijaksana, jujur, setia, cakap, tidak berkhianat, dan pemberani. Pangeran Kornel merupakan manusia yang tidak takut mengungkap kebenaran. Hal itu terbukti ketika dia mengungkap kebenaran kepada Mas Galak Daendels. Dalam berbagai sumber disebutkan bahwa peristiwa tersebut berkaitan dengan pembuatan Jalan Cadas Pangeran yang dikenal dengan Jalan Raya Pos/Grote Postweg (Suryaningrat, 1983, hlm. 94-96). Hal ini menjadi bukti autentik bahwa Pangeran Kornel bukan fiksi melainkan tokoh nyata dalam sejarah. Walaupun namanya ada dalam karya sastra, bukan berarti nama tokoh tersebut fiksi, tetapi sebagai bukti penghormatan dan juga pengenalan kepada masyarakat agar tokoh Pangeran Kornel tetap dikenang.

Diangkatnya nama Pangeran Kornel dalam sastra dan sejarah menjadi bukti bahwa nama tokoh tersebut mempunyai keistimewaan dibandingkan dengan tokoh bupati lainnya, terutama di Sumedang, tetapi bukan berarti bupati lainnya tidak mempunyai kharisma, namun karena tokoh Pangeran Kornel mencetak sejarah perlawanan terhadap VOC dan Pemerintahan Hindia Belanda pada waktu itu, khususnya ketika proses pembuatan Jalan Cadas Pangeran yang dilakukan oleh Gubernur Jenderal Hindia Belanda, Herman Willem Daendels.

Pada awal pembuatan Jalan Cadas Pangeran, rakyat Sumedang yang bekerja dalam pembuatan jalan tersebut banyak merasakan penderitaan, hingga suatu waktu Pangeran Kornel melakukan protes terhadap Daendels. Bentuk protes yang 
dilakukan oleh Pangeran Kornel tersebut hingga sekarang diabadikan dalam sebuah patung yang sedang bersalaman antara Daendels dan Pangeran Kornel yang terdapat di Jalan Cadas Pangeran. Selain adanya perlawanan yang dilakukan oleh Pangeran Kornel terhadap Gubernur Jenderal Hindia Belanda, pada masa pemerintahan beliau juga, Kabupaten Sumedang mengalami banyak kemajuan dalam berbagai bidang. Salah satu contohnya, luas wilayah kekuasaan Kabupaten Sumedang semakin bertambah hingga 15 distrik (Lubis, dkk., 2008, hlm. 159-160).

Sebelumnya, terdapat beberapa tulisan dan penelitian yang serupa dengan penelitian ini. Tulisan tersebut di antaranya "Mendekonstruksi Mitos Pembangunan Jalan Raya Cadas Pangeran 1808: Komparasi Sejarah dan Tradisi Lisan" (Marihandono, 2008), yang membahas tentang proses pembuatan Jalan Cadas Pangeran dan didapatkan hasil bahwa proses pembuatan Jalan Cadas Pangeran berdampak pada kehidupan politik dan sosial masyarakat. Selain itu, dalam artikel ini juga terungkap bahwa polarisasi politik yang terjadi selama pemerintahan Daendels bukan hanya berpengaruh pada orang Eropa, tapi juga bagi orang pribumi, lalu ditemukan adanya upaya penghapusan pengaruh kekuasaan dari rezim sebelumnya, dan cerita Cadas Pangeran ini merupakan mitos. Selanjutnya, terdapat penelitian lain yang dilaksanakan oleh Handayani, dkk. (2019) dengan judul "Rekam Jejak Pangeran Aria Soeria Atmadja (Bupati Sumedang Tahun 1883-1919)" dan didapatkan hasil bahwa Pangeran Aria Soeria Atmadja banyak menghabiskan waktunya untuk menimba ilmu baik itu ilmu pendidikan umum, bahasa maupun ilmu agama Islam melalui pesantren. Selain itu, semua kebijakan yang dilakukannya tidak lain dan tidak bukan hanya untuk menyejahterakan rakyat.

Berdasarkan penelitian yang telah dibahas sebelumnya, terdapat adanya persamaan dan perbedaan dengan penelitian yang dilaksanakan. Persamaannya yaitu adanya sinkronisasi dengan nama tempat Cadas Pangeran dan nama bupati Sumedang dengan penelitian yang dilakukan oleh Marihandono (2008) dan Handayani, dkk. (2019). Adapun perbedaannya bisa dilihat dari teori, metode, dan hal lain yang menjadi fokus utama garapannya. Penelitian yang dilaksanakan lebih mengungkap pada kajian sastra dan sejarah tentang tokoh Pangeran Kornel, sedangkan tulisan Marihandono (2008) lebih fokus pada sejarah dan proses pembangunan Jalan Cadas Pangerannya, begitupun penelitian Handayani, dkk. (2019) lebih fokus terhadap tokoh bupati setelah Pangeran Kornel, yaitu Pangeran Aria Soeria Atmadja.

Maka berdasarkan pada pemaparan latar belakang tersebut, tujuan ditulisnya artikel penelitian ini yaitu untuk mendeskripsikan cerita Pangeran Kornel dalam perspektif sastra dan sejarah, serta hubungan di antara keduanya. Landasan teori yang digunakannya yaitu teori struktural karya sastra yang dikemukakan oleh Stanton (2012), meliputi tema, fakta cerita, dan sarana sastra. Teori tersebut digunakan untuk menganalisis struktur karya sastra novel Pangéran Kornél karya R. Memed Sastrahadiprawira. Selain teori tersebut, digunakan juga teori sejarah yang dikemukakan oleh Sjamsuddin (2007, hlm. 86) yang terdiri dari heuristik, kritik sumber, dan historiografi sebagai landasan teori untuk mengungkap sisi kesejarahan cerita Pangeran Kornel.

\section{B. METODE}

Metode yang digunakan untuk menulis artikel ini yaitu metode deskriptif dan metode historis (sejarah), sedangkan pendekatan yang digunakannya menggunakan 
pendekatan kualitatif. Teknik yang digunakan meliputi teknik studi pustaka, studi dokumentasi, dan wawancara. Teknik studi pustaka digunakan untuk menelaah dan mengidentifikasi bahan bacaan yang berkaitan dengan penelitian; teknik studi dokumentasi digunakan untuk mencari informasi tertulis pada buku, jurnal, esai, dan sumber tertulis lainnya yang berkaitan dengan penelitian; sedangkan wawancara digunakan untuk mencari informasi langsung dari narasumber yang berkaitan dengan penelitian dengan cara terjun langsung ke lapangan.

Teori yang digunakannya yaitu teori struktur karya sastra Stanton (2012) yang membagi struktur pembangun cerita menjadi tiga hal, yaitu tema, fakta cerita, dan sarana sastra. Selain teori struktur Robert Stanton, dalam artikel ini juga digunakan teori dan metode sejarah Sjamsuddin (2007, hlm. 86) yang terdiri dari heuristik, kritik sumber, dan historiografi.

Sumber data yang digunakan yaitu buku novel Pangéran Kornél karya R. Memed Sastrahadiprawira (terbitan Kiblat, 2014) dan juga buku sejarah yang berkaitan dengan Pangeran Kornel yang meliputi buku Rucatan Budaya Sumedang karya WD. Dharmawan Wangsapurwacaraka (1994) dan Sejarah Sumedang dari Masa ke Masa karya Nina H. Lubis, dkk. (2008). Selain itu, sumber data yang digunakan juga ditambahkan dengan hasil wawancara khusus dengan dua orang pengurus Museum Prabu Geusan Ulun, yaitu Bapak Abdul Sukur dan Ibu Rd. Fetty Soemawilaga (Kepala Bidang Perpustakaan Museum Prabu Geusan Ulun, Sumedang). Instrumen penelitian yang digunakan terbagi menjadi dua, yaitu instrumen untuk mengumpulkan data dan instrumen untuk mengolah data. Instrumen mengumpulkan data meliputi instrumen tabel checklist dokumentasi dan instrumen wawancara, sedangkan instrumen mengolah data yaitu kartu data.

Langkah-langkah penelitian meliputi: (1) persiapan, peneliti merumuskan masalah dan membuat instrumen penelitian; (2) mengumpulkan data, dengan cara teknik studi pustaka, studi dokumentasi, dan wawancara; (3) mengolah data, menganalisis, dan menafsirkan data menggunakan instrumen analisis untuk mengolah data, yaitu kartu data; (4) membuat simpulan; serta (5) menyusun laporan dan artikel penelitian.

\section{PEMBAHASAN}

\section{Pangeran Kornel dalam Perspektif Sastra}

Novel Pangéran Kornél karya R. Memed Sastrahadiprawira merupakan novel yang tergolong ke dalam novel sejarah. Seperti yang pernah dikemukakan oleh Darajat, dkk. (2020, hlm. 11) bahwa novel sejarah isinya berkaitan dengan peristiwa sejarah. Novel Pangéran Kornél memiliki struktur cerita yang lengkap sesuai dengan teori yang dikemukakan oleh Stanton (2012), meliputi tema, fakta cerita, dan sarana sastra.

Novel ini menceritakan tentang perjalanan hidup Raden Jamu atau yang dikenal dengan sebutan Pangeran Kornel, dari masa kecil hingga dia diangkat menjadi bupati di Kabupaten Sumedang. Dalam novel tersebut diceritakan bahwa semasa kecilnya Raden Jamu sudah hidup mandiri, ayahnya yang bernama Pangeran Adipati Surianagara telah meninggal dunia waktu Raden Jamu masih kecil, sehingga kekuasaan kabupaten tidak diberikan kepada Raden Jamu, namun untuk sementara digantikan terlebih dahulu oleh pamannya (adik ayahnya) dan dilanjutkan lagi oleh bupati dari Parakanmuncang hingga Raden Jamu tumbuh dewasa, tapi janji dari Bupati Parakanmuncang tersebut tidak ditepati, bahkan Pangeran Kornel difitnah 
oleh demang kepercayaan bupati tersebut, hingga akhirnya Pangeran Kornel pergi berkelana ke Limbangan dan ke Cianjur untuk menemui Bupati Cianjur, karena kegigihan dan ketekunannya, Raden Jamu dipercaya oleh Bupati Cianjur dan diangkat menjadi Kepala Cutak Cikalong. Diceritakan di Sumedang, bupati yang memegang kekuasaan tersebut terhasut oleh Demang Dongkol. Demang Dongkol merupakan orang licik yang memanfaatkan kekuasaan Bupati Parakanmuncang, tapi Demang Dongkol akhirnya mati terbunuh, dan bupati yang berasal dari Parakanmuncang itu diturunkan kekuasaannya oleh pemerintah Hindia Belanda dan Raden Jamu diangkat menjadi bupati di Sumedang berkat bantuan Raden Aria Wiratanudatar (Bupati Cianjur), dan sejak saat itu Kabupaten Sumedang menjadi salah satu kabupaten yang berkuasa dan maju. Sejak Raden Jamu diangkat menjadi bupati, terdapat beberapa permasalahan yang menimpa dirinya dan pemerintahannya, dari mulai masalah pembangunan Jalan Cadas Pangeran, pengusiran dan perlawanan perompak/ bajak laut, dan lain-lain. Akhir dari ceritanya, Pangeran Kornel dikenang menjadi bupati yang berpengaruh di Kabupaten Sumedang dan wafat pada tanggal 29 Juli 1828.

Adapun struktur novel tersebut dapat diruntut sebagai berikut.

\section{a. Tema}

Tema yang diangkat dalam novel ini yaitu berkaitan dengan kehidupan sosial dan kepemimpinan, yang menceritakan tentang kehidupan Pangeran Kornel dari masa kecil hingga dia diangkat menjadi seorang bupati yang sangat berpengaruh dalam kepemimpinannya di Kabupaten Sumedang.

Tema tersebut dapat terlihat dari beberapa poin dan konflik yang membangun cerita, meliputi 1) politik kepemimpinan, 2) pendidikan kepemimpinan, 3) relasi dan hubungan kenegaraan, 4) percintaan, 5) kejahatan yang tidak akan kekal, 6) suksesi kepemimpinan yang salah, dan 7) kebenaran akan selalu menang.

Semua konflik dan poin permasalahan-permasalahan tersebut dapat terlihat dari proses perjalanan kehidupan yang dialami oleh Raden Jamu dari masa kecil hingga diangkat menjadi bupati.

\section{b. Fakta Cerita}

Fakta cerita dalam novel ini meliputi alur/plot, tokoh/penokohan, dan latar.

\section{1) Alur/plot}

Alur/plot dalam novel ini dianalisis dari 23 episode/bagian, tiap episode/bagiannya itu terdapat rangkaian kejadian dan peristiwa yang tersusun secara logis dan kronologis, sehingga tersusun suatu alur/plot yang menggerakkan cerita. Untuk lebih jelasnya bisa dilihat pada Tabel 1.

\section{2) Tokoh/penokohan}

Tokoh dalam novel ini terbagi menjadi dua, yaitu tokoh utama dan tokoh tambahan. Nurgiyantoro (2013, hlm. 176) pernah menyebutkan bahwa tokoh mempunyai peranan yang sangat penting dalam suatu cerita, sebab bisa menghidupkan suasana cerita. Tokoh utama dalam novel ini yaitu Pangeran Kornel (Raden Jamu), sedangkan tokoh tambahannya terbagi menjadi dua jenis, yaitu tokoh tambahan yang mendampingi tokoh utama dan tokoh tambahan yang benar-benar tokoh tambahan. 
Tokoh tambahan yang mendampingi tokoh utama seperti Juragan Patih, Demang Dongkol, Dalem/Pangawulaan Parakanmuncang, Demang Mangkupraja, dan lain-lain. Lalu tokoh yang benar-benar tokoh tambahan adalah istri Demang Dongkol, anak Demang Dongkol, Pangeran Dipanagara, Bagus Rangin, dan lainlain.

\section{3) Latar}

Seperti yang dikemukakan oleh Abrams (dalam Nurgiyantoro, 2013, hlm. 217), bahwa latar atau setting biasanya menunjukkan pada tempat, hubungan waktu, dan lingkungan sosial. Latar yang terdapat dalam novel ini terdiri atas latar tempat, waktu, dan sosial. Oleh sebab itu bisa disebutkan bahwa seluruh latar terdapat dalam novel ini.

Latar tempat yang terdapat dalam novel ini yaitu Limbangan, Ciayunan, Dayeuh Parakanmuncang, Cikalong, Cikundul, dan lain-lain. Untuk lebih jelasnya bisa dilihat pada kutipan berikut ini.

Salilana Radén Suria aya di Limbangan, pada ngarubung-rubung baé. Para kiai ti pasantrén, sumawonna para ulama nu araya di dayeuh, rabul saban poé ngadareuheus ka padaleman ngalayad Radén Suria (Sastrahadiprawira, 2014, hlm. 55).

Kira-kira wanci Asar Radén Suria sumping ka lembur Ciayunan, ti dinya mah geus deukeut ka dayeuh Parakanmuncang (Sastrahadiprawira, 2014, hlm. 57).

Cikalong dina taun 1780. Tempat tiiseun pisan, tapi sanajan kitu geueuman, sabab éta tempat asal nagara sasaka, pangcalikanana para luluhur nu ngarundaykeun para bupati Cianjur, waktu dayeuhna di Cikundul kénéh (Sastrahadiprawira, 2014, hlm. 81).

\section{Terjemahan:}

Selama Raden Suria ada di Limbangan, orang-orang pada menemuinya. Para Kiai dari pesantren, begitu pun para ulama yang ada di pusat kota, semua pada datang ke padaleman ingin menemui Raden Suria (Sastrahadiprawira, 2014, hlm. 55).

Kira-kira waktu Asar Raden Suria datang ke Kampung Ciayunan, dari sana sudah dekat ke pusat kota Parakanmuncang (Sastrahadiprawira, 2014, hlm. $57)$.

Cikalong pada tahun 1780. Tempat yang sangat sepi, tapi walaupun sangat sepi dan menakutkan, tempat tersebut merupakan tempat awal yang melahirkan para leluhur bupati Cianjur, waktu pusat kotanya masih di Cikundul (Sastrahadiprawira, 2014, hlm. 81).

Latar waktu yang terdapat dalam novel ini sangat tegas sekali, karena lebih banyak menyebutkan tahun dengan angka, seperti pada tahun 1773, 1780, 1791, 26 November-12 Maret 1821, dan lain-lain. Selain itu, terdapat latar waktu lain di 
antaranya seperti subuh-subuh (hlm. 56), wanci asar (hlm. 57), isukna (hlm. 89) dan hiji soré (hlm. 96).

Selanjutnya, latar waktu dalam novel ini juga berkaitan dengan latar sosial, hal tersebut dapat terlihat dari adanya stratifikasi sosial atau tingkatan sosial yang tergambar dalam novel, seperti adanya sebutan: 1) Pangawulaan, 2) Kangjeng Dalem, 3) Kiai, 4) rahayat, 5) Demang, dan lain-lain. Dengan adanya hal tersebut akhirnya bisa dikelompokkan bahwa tingkatan sosial dalam novel ini terdiri atas: 1) tingkatan menak atau pamongpraja (bangsa kolonial dan menak pribumi), 2) tingkatan menengah atau pesantren, dan 3) tingkatan cacah atau rakyat. Hal tersebut terbukti dari adanya nama-nama yang menggunakan awalan Radén, Kangjeng Dalem, Juragan Patih, Demang, Kiai, Tuan Marsekal, dan lain-lain.

\section{c. Sarana Sastra}

Sarana sastra dalam novel ini terbagi menjadi tiga, yaitu judul, sudut pandang, dan gaya bahasa.

\section{1) Judul}

Judul novel ini Pangéran Kornél. Judul dan isi ceritanya mempunyai hubungan dan sudah sangat sesuai. Hal tersebut dapat terlihat dari isinya yang menceritakan tentang perjalanan kehidupan Raden Jamu, putra dari Adipati Surianagara Bupati Sumedang periode 1761-1765. Sepeninggal ayahnya itu, Raden Jamu menjalani kehidupan secara mandiri, karena posisi bupati digantikan oleh adik dari ayahnya dan dilanjutkan oleh Dalem Parakanmuncang sampai Raden Jamu dewasa. Dalam proses perjalanan hidupnya itu, Raden Jamu banyak belajar. Dia pun berkelana ke wilayah Limbangan, Cianjur, hingga akhirnya diangkat menjadi bupati yang sangat berpengaruh di Kabupaten Sumedang dan mendapat sebutan nama Pangeran Kornel. Maka dari itu, novel ini diberi judul Pangeran Kornel, karena menceritakan perjalanan hidup Raden Jamu/Pangeran Kornel dari kecil hingga dewasa.

Judul Pangeran Kornel memiliki beberapa tingkatan makna, yaitu 1) jadi manusia harus sabar, seperti halnya Raden Jamu, walaupun difitnah, dia tetap sabar, karena setiap kejahatan akhirnya akan terkalahkan oleh kebenaran; 2) perjalanan menjadi manusia yang terbaik itu tidak mudah, semuanya akan melewati berbagai hal, dari mulai rintangan, tantangan, pengorbanan, dan lain-lain; dan 3) pemimpin yang hebat tidak dilahirkan dengan cara yang mudah, semuanya melewati berbagai proses, baik itu proses tantangan untuk dirinya maupun proses pembentukan karakter dan juga pendidikan, seperti halnya Raden Jamu yang mengalami berbagai tantangan dan juga menjalani proses pendidikan.

\section{2) Sudut Pandang}

Sudut pandang yang digunakan pengarang dalam menyampaikan ceritanya yaitu menggunakan sudut pandang orang ketiga-tidak terbatas. Hal tersebut dapat terlihat dari penyampaiannya yang lebih bebas, serba tahu, dan tidak memusat pada diri pengarangnya saja, tetapi lebih luas, dan setiap kejadiannya lebih bebas diceritakan. Sebagaimana yang dikemukakan oleh Stanton (2012, hlm. 53), bahwa sudut pandang orang ketiga-tidak terbatas, pengarang mengendalikan semua karakter dan memosisikan dirinya menjadi orang ketiga. Seterusnya, pengarang juga bisa membuat beberapa karakter untuk melihat, mendengar, dan berpikir, walaupun tidak ada karakter yang diceritakannya. Hal tersebut sesuai dengan model 
penceritaan dalam novel Pangéran Kornél. Oleh sebab itu, sudut pandang yang digunakannya, yaitu orang ketiga-tidak terbatas.

\section{3) Gaya Bahasa}

Gaya bahasa yang digunakan oleh pengarang dapat diklasifikasikan berdasarkan ragam bahasanya, yaitu 1) ragam bahasa menak Sunda; 2) ragam bahasa abdi dalem; ragam bahasa bangsa Kolonial; 3 ) ragam bahasa para Kiai (kaum agamawan); dan 4) ragam bahasa cacah/rakyat, namun secara umum gaya bahasa yang terdapat dalam novel ini meliputi gaya bahasa litotes, gaya bahasa pleonasme, gaya bahasa metafora, gaya bahasa alegori, gaya bahasa perifrase/perifrastis, dan gaya bahasa hiperbola. Hal tersebut sejalan dengan yang dikemukakan oleh Iskandarwassid (2019, hlm. 66), bahwa gaya bahasa merupakan corak ekspresi bahasa baik dalam bentuk puisi maupun dalam bentuk prosa; gaya bahasa juga merupakan suatu cara yang digunakan oleh pengarang untuk menyampaikan ucapan, biasanya sifat dalam gaya bahasa tersebut dapat terlihat melalui diksi, ungkapan kalimat, macam-macam perbandingan dan penekanan arti, pola irama, dan ciri-ciri bentuk lainnya, atau rakitan bahasa. Pengarang novel Pangéran Kornél telah melakukan penceritaan sesuai dengan pembahasan tersebut, hal itu dapat terlihat dari diksi, ungkapan kalimat, pola irama, dan lain-lain.

Setelah melihat pembahasan tentang struktur cerita novel Pangéran Kornél. Maka dapat disebutkan bahwa Pangeran Kornel dalam perspektif sastra, khususnya yang diceritakan dalam novel Pangéran Kornél karya R. Memed Sastrahadiprawira secara keseluruhan isinya berasal dari cerita rakyat yang sebelumnya berkembang di masyarakat, semisal tradisi lisan masyarakat Kabupaten Sumedang. Setelah dianalisis, cerita novel tersebut sesuai dengan bukti-bukti sejarah yang ada di Kabupaten Sumedang. Hal tersebut dapat terlihat dari adanya latar waktu dan tempat yang sesuai dengan fakta-fakta sejarah.

Pangeran Kornel dalam perspektif sastra juga bukan hanya ada dalam bentuk novel seperti yang ditulis oleh $\mathrm{R}$. Memed Sastrahadiprawira. Ternyata cerita Pangeran Kornel juga pernah ada dalam bentuk karya sastra puisi (sajak) seperti yang pernah ditulis oleh Yus Rusyana, dengan judul Cadas Pangéran. Dengan adanya hal tersebut dapat disimpulkan bahwa tokoh Pangeran Kornel ini erat kaitannya dengan proses pembuatan Jalan Cadas Pangeran, yang secara umum banyak dikenal oleh masyarakat dan mempunyai nilai tambah sebagai seorang tokoh bupati, sehingga banyak cerita yang berkembang di masyarakat, baik dalam bentuk tradisi lisan, seperti dongeng, maupun dalam bentuk karya sastra tulis, yang sebenarnya merupakan suatu bentuk penceritaan ulang dan pendokumentasian agar tokoh Pangeran Kornel itu tetap dikenal oleh masyarakat.

\section{Pangeran Kornel dalam Perspektif Sejarah}

Dalam perspektif sejarah, analisis dilakukan berdasarkan metode yang dikemukakan oleh Sjamsuddin (2007, hlm. 86) yang terdiri atas heuristik, kritik sumber, dan historiografi.

Tokoh Pangeran Kornel dalam perspektif sejarah dapat dimaknai sebagai seorang tokoh yang sangat berpengaruh dalam proses perjalanan pemerintahan Kabupaten Sumedang. Berdasarkan catatan sejarah, Lubis, dkk. (2008) menyebutkan bahwa tokoh Pangeran Kornel atau yang mempunyai nama lengkap Raden Tumenggung Adipati Aria Surianagara merupakan seorang bupati yang pada masa 
pemerintahannya, Kabupaten Sumedang mengalami banyak kemajuan dalam berbagai bidang, baik dari segi kewilayahan, ekonomi, maupun pemerintahan.

Selain berdasarkan historiografi, sebagai bukti adanya tokoh Pangeran Kornel dalam sejarah Kabupaten Sumedang, peneliti juga melakukan peninjauan dan penyelidikan langsung ke lapangan. Hal tersebut dilakukan untuk memastikan bahwa Jalan Cadas Pangeran itu benar adanya, lalu di jalan tersebut terdapat suatu prasasti yang isinya menjelaskan tentang pembangunan Jalan Cadas Pangeran. Dalam prasasti tersebut terdapat tulisan dalam bahasa Belanda, untuk lebih jelasnya bisa dilihat pada kutipan berikut ini.

\section{Onder leiding van Rd. Demang \\ Mangkoepradja en onder toezicht \\ van Pangeran Koesoemahdinata \\ Aangelegd 1811 \\ Doorgekapt 26 November \\ tot 12 Maart 1812.}

(Sumber: Prasasti Pembuatan Jalan Raya Cadas Pangeran).

\section{Terjemahan:}

Di bawah pimpinan Raden Demang

Mangkoepradja dan di bawah penelitian

Pangeran Koesoemahdinata

Dibuat pada tahun 1811

Dibobok dari tanggal 26 November

sampai 12 Maret 1812.

(Sumber: Prasasti Pembuatan Jalan Raya Cadas Pangeran).

Kutipan prasasti tersebut menjadi salah satu bukti, bahwa di bawah kepemimpinan Pangeran Kornel, Jalan Cadas Pangeran dibangun dan mengalami masa renovasi atau perbaikan. Selain itu, data lainnya didapat dari wawancara langsung terhadap dua orang pengurus Museum Prabu Geusan Ulun. Pengurus Museum menyebutkan bahwa Pangeran Kornel memimpin Kabupaten Sumedang sekitar tahun 1791 sampai dengan 1828. Nama Pangeran Kornel itu merupakan nama pangkat, nama aslinya yaitu Raden Jamu Surianagara atau Pangeran Koesoemahnagara/Pangeran Koesoemahdinata (Sukur dan Soemawilaga, 2021).

Dengan demikian dapat disimpulkan bahwa tokoh Pangeran Kornel dalam perspektif sejarah tidak berbeda jauh dengan yang disebutkan dalam karya sastra. Tokoh Pangeran Kornel merupakan tokoh bupati yang sangat berpengaruh terutama pada masa pemerintahannya. Selain itu, tokoh tersebut juga dikenal sebagai tokoh bupati yang berani dan berperan besar dalam pembuatan Jalan Raya Pos (Grote Postweg). Pada masa pemerintahannya, Pangeran Kornel membuka pintu kemajuan yang mendatangkan pujian dari orang Belanda, sebagaimana yang tertuang dalam surat berikut ini.

"Ik geloog inderdadd, dat door het hale leven van dazen regentals enn roode dradd het streven loopt, omde oude opperlandbooggij in sijn persoon herteld te sien, evvenals Zulks met zijn in 1709, opgetraden voorvader en den ouden Ranggagempol het gevel was gewwest, en doordi successieve toefoeging wan nieu landen kwam hij dit noel nu endan 
vrij nabij". (Preanger Redeschappen, hlm. 166., dalam Wangsapurwacaraka, 1994, hlm. 127).

\section{Terjemahan:}

Saya telah berbohong bahwa sepanjang hidup para bupati yang sebelumnya, yang jauh dari jalan keturunan yang benar, sebenarnya aspirasi tetap mengalir agar lengkungan tanah atas (Sumedang) yang telah lama dipulihkan dalam dirinya (Pangeran Kornel) dan oleh leluhurnya yang telah meninggal pada tahun 1709 juga Ranggagempol, telah terjadi keonaran/kerusakan, tapi akhirnya setelah ada penambahan berturut-turut negara baru, dia (Pangeran Kornel) datang cukup dekat dengan ini sekarang dan kemudian (Preanger Redeschappen, hlm. 166., dalam Wangsapurwacaraka, 1994, hlm. 127).

Inti dari surat pernyataan tersebut merupakan bentuk pujian kepada Pangeran Kornel yang merupakan keturunan dari Ranggagempol, dikarenakan telah berhasil memerhatikan stabilitas keamanan dan menciptakan keamanan di Kabupaten Sumedang. Selain itu, Pangeran Kornel juga merupakan bupati yang sukses dalam memimpin dan dianggap sangat dekat oleh bangsa Belanda. Bentuk kedekatan tersebut sebenarnya dimanfaatkan oleh Pangeran Kornel untuk memajukan tanah pribuminya. Selain itu, dapat dikatakan bahwa Pangeran Kornel ini mempunyai keterampilan dalam membina hubungan sosial, sebagaimana yang dikatakan oleh Goleman (2006); Kurnia dan Zahro (2021), bahwa keterampilan membina hubungan akan memungkinkan seseorang membentuk dan mempertahankan hubungan, untuk menggerakkan orang lain, membina kedekatan hubungan, meyakinkan, serta membuat orang lain merasa nyaman. Hal tersebut dilakukan oleh Pangeran Kornel yang membuat dirinya dekat dengan orang Belanda. Sehingga secara tidak langsung kondisi seperti itu dimanfaatkan olehnya sebagai bentuk kerja sama yang dapat memperkuat wilayah kekuasaannya.

\section{Sinkronisasi Tokoh Pangeran Kornel dalam Sastra dan Sejarah}

Terdapat hubungan yang sangat erat antara tinjauan kesastraan dan kesejarahan terhadap cerita Pangeran Kornel dan dalam ranah sastra, cerita tersebut bersumber dari tradisi lisan dan fakta sejarah yang ada. Maka dapat dikatakan bahwa peristiwa sejarah telah menstimulasi munculnya karya sastra yang berkisah tentang Pangeran Kornel. Bukti adanya keterkaitan antara cerita Pangeran Kornel dalam sastra dengan sejarah, dapat dilihat pada Tabel 2. 
Tabel 1. Alur Novel Pangéran Kornél

\begin{tabular}{|c|c|c|c|}
\hline No. & Alur & Isi & Episode \\
\hline 1. & Situation & $\begin{array}{l}\text { Pada tahap ini, pengarang memperkenalkan keadaan Kabupaten } \\
\text { Sumedang yang sudah terpengaruh oleh keadaan orang luar } \\
\text { (ninggang kana cacandran Sumedang ngarangrangan). Selain itu, } \\
\text { pengarang juga menggambarkan situasi tanah Priangan yang } \\
\text { banyak didatangi oleh orang luar dan keadaan Bandung heurin ku } \\
\text { tangtung. }\end{array}$ & $1-2$ \\
\hline 2. & $\begin{array}{l}\text { Generating } \\
\text { Circumstances }\end{array}$ & $\begin{array}{l}\text { Pada tahap ini, pengarang memunculkan awal pembawa konflik } \\
\text { yaitu ketika Pangawulaan Dalem Parakanmuncang kedatangan } \\
\text { tamu yang bernama Demang Dongkol. }\end{array}$ & $2-3$ \\
\hline 3. & Rising Action & $\begin{array}{l}\text { Pada tahap ini, keadaan dan situasi cerita sudah mulai } \\
\text { memuncak, Demang Dongkol menjadi kepercayaan Dalem } \\
\text { Sumedang yang baru. Pada tahap ini juga, kejahatan dan } \\
\text { kelicikan Demang Dongkol sudah mulai terlihat dengan jelas. } \\
\text { Pada tahap ini juga terdapat pengenalan sosok Raden Jamu dan } \\
\text { penceritaan sosok orang licik (Demang Dongkol) yang } \\
\text { diceritakan oleh Juragan Patih kepada Raden Jamu. }\end{array}$ & $4-5$ \\
\hline 4. & Climax & $\begin{array}{l}\text { Klimaks yang terdapat dalam novel ini dibagi ke dalam beberapa } \\
\text { tahap. Pertama, ketika kejadian di Tegal Licin. Kedua, ketika } \\
\text { Raden Jamu difitnah oleh Demang Dongkol. Ketiga, ketika } \\
\text { Demang Dongkol terbunuh. Keempat, ketika pengangkatan } \\
\text { Raden Jamu menjadi bupati. Kelima, ketika pertemuan } \\
\text { Pangawulaan dengan Tuan Marsekal dan memberikan salam } \\
\text { dengan tangan kiri. Keenam ketika terjadi perang Bantarjati. } \\
\text { Ketujuh, ketika Kangjeng Dalem memuji Nederland/Belanda di } \\
\text { hadapan Inggris. Kedelapan, ketika penjagaan. } \\
\text { Walaupun begitu, klimaks yang menjadi puncak ceritanya yaitu } \\
\text { ketika Raden Jamu difitnah oleh Demang Dongkol dan ketika } \\
\text { Raden Jamu/Pangeran Kornel bersalaman dengan Tuan } \\
\text { Marsekal. }\end{array}$ & $6-22$ \\
\hline 5. & Denoument & $\begin{array}{l}\text { Sebenarnya proses penyelesaian konflik pada novel ini langsung } \\
\text { disimpan setiap selesai klimaks. Jadi setiap ada klimaks, } \\
\text { pengarang langsung memberikan penyelesaiannya, tetapi } \\
\text { akhir/penyelesaian cerita dalam novel ini yaitu ketika Raden } \\
\text { Jamu wafat, pada tanggal } 29 \text { Juli } 1828 \text {. Ketika itu keadaan } \\
\text { Sumedang dan sekitarnya sangat kehilangan dan suasananya } \\
\text { berbeda sekali dari biasanya. Pada akhir cerita/denoument ini, } \\
\text { pengarang menyajikan suasana dalam bentuk karya puisi. }\end{array}$ & 23 \\
\hline
\end{tabular}




\section{Tabel 2. Keterkaitan Cerita Pangeran Kornel dalam Sastra dan Sejarah}

\begin{tabular}{|c|c|c|c|}
\hline No. & Sastra & Sejarah & Keterkaitan \\
\hline 1. & $\begin{array}{l}\text { Dalam sastra nama kecil } \\
\text { Pangeran Kornel adalah } \\
\text { Raden Jamu. }\end{array}$ & $\begin{array}{l}\text { Dalam sejarah pun sama, } \\
\text { nama kecil Pangeran Kornel } \\
\text { adalah Raden Jamu. }\end{array}$ & $\begin{array}{l}\text { Terdapat persamaan di antara } \\
\text { keduanya. }\end{array}$ \\
\hline 2. & $\begin{array}{l}\text { Dalam sastra terdapat } \\
\text { nama Demang Dongkol } \\
\text { yang berkhianat, licik, } \\
\text { dan jahat terhadap } \\
\text { Raden Jamu. }\end{array}$ & $\begin{array}{l}\text { Dalam buku Sejarah } \\
\text { Sumedang dari Masa ke Masa } \\
\text { karya Nina H. Lubis, dkk., } \\
\text { (2008) hanya disebutkan } \\
\text { seorang demang saja. }\end{array}$ & $\begin{array}{l}\text { Terdapat persamaan di antara } \\
\text { keduanya, namun dalam sastra } \\
\text { ditambahkan nama "dongkol" } \\
\text { sebagai maksud untuk } \\
\text { menyebutkan seseorang yang } \\
\text { telah diberhentikan dari } \\
\text { pekerjaannya secara hormat } \\
\text { (Danadibrata, 2015, hlm. 175). } \\
\text { Artinya, Demang Dongkol itu } \\
\text { seorang demang yang sudah } \\
\text { pensiun. }\end{array}$ \\
\hline 3. & $\begin{array}{l}\text { Dalam sastra, Pangeran } \\
\text { Kornel berkelana ke } \\
\text { Limbangan, lalu } \\
\text { melanjutkan perjalanan } \\
\text { ke Parakanmuncang, } \\
\text { melewati Nagreg, } \\
\text { Ciayunan, Citarik, dan } \\
\text { akhirnya sampai di } \\
\text { Cianjur sekitar tahun } \\
\text { 1780. Mengenai } \\
\text { pengangkatan menjadi } \\
\text { wedana, tidak } \\
\text { disebutkan secara pasti } \\
\text { tahunnya, hanya } \\
\text { disebutkan sekitar tahun } \\
\text { 1780. }\end{array}$ & $\begin{array}{l}\text { Dalam sejarah, Pangeran } \\
\text { Kornel berkelana ke } \\
\text { Limbangan dan pindah ke } \\
\text { Cianjur, lalu pada tahun } 1788 \\
\text { diangkat menjadi Kepala } \\
\text { Cutak (wedana) Cikalong. }\end{array}$ & $\begin{array}{l}\text { Terdapat persamaan di antara } \\
\text { keduanya, namun dalam sastra } \\
\text { sengaja dibuat lebih rinci. Hal } \\
\text { tersebut agar menambah } \\
\text { suasana dan imajinasi pembaca. } \\
\text { Mengenai titimangsa juga, di } \\
\text { antara keduanya tidak beda } \\
\text { jauh, yaitu sekitar tahun 1780- } \\
\text { an. }\end{array}$ \\
\hline 4. & $\begin{array}{l}\text { Dalam sastra, Pangeran } \\
\text { Kornel mulai diangkat } \\
\text { menjadi bupati } \\
\text { Sumedang sekitar tahun } \\
1791 \text { Namanya } \\
\text { berubah menjadi Raden } \\
\text { Tumenggung } \\
\text { Surianagara. }\end{array}$ & $\begin{array}{l}\text { Dalam sejarah pun sama } \\
\text { bahwa Pangeran Kornel } \\
\text { diangkat menjadi bupati pada } \\
\text { tanggal } 30 \text { Desember } 1791 \\
\text { melalui besluit dan mendapat } \\
\text { gelar "tumenggung". }\end{array}$ & Keduanya terdapat persamaan. \\
\hline 5. & $\begin{array}{lr}\text { Dalam sastra } & \text { terdapat } \\
\text { penjelasan } & \text { tentang } \\
\text { prasasti } & \text { yang } \\
\text { menunjukkan } & \\
\text { pembangunan } & \text { Jalan } \\
\text { Cadas Pangeran. } & \end{array}$ & $\begin{array}{l}\text { Dalam sejarah pun sama, } \\
\text { terdapat prasasti yang } \\
\text { terletak di Jalan Cadas } \\
\text { Pangeran sebagai bukti } \\
\text { bahwa di bawah Demang } \\
\text { Mangkoepradja r dan } \\
\text { Pangeran Koesoemahdinata } \\
\text { Jalan Cadas Pangeran } \\
\text { dibangun. }\end{array}$ & $\begin{array}{l}\text { Terdapat persamaan di antara } \\
\text { keduanya. Namun ditemukan } \\
\text { juga perbedaan. Dalam sastra } \\
\text { dibangun pada tahun 1821, } \\
\text { sedangkan dalam bukti } \\
\text { sejarahnya disebutkan bahwa } \\
\text { jalan tersebut dibangun pada } \\
\text { tahun 1811 dan selesai } \\
\text { direnovasi pada bulan Maret } \\
\text { tahun 1812. }\end{array}$ \\
\hline 6. & 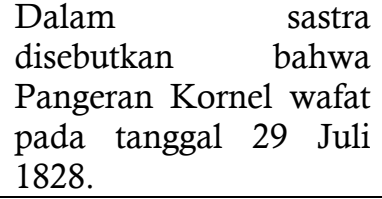 & $\begin{array}{l}\text { Dalam sejarah pun } \\
\text { disebutkan bahwa Pangeran } \\
\text { Kornel wafat pada tanggal } 29 \\
\text { Juli } 1828 \text { dan dimakamkan di }\end{array}$ & $\begin{array}{l}\text { Terdapat kesamaan di antara } \\
\text { keduanya. }\end{array}$ \\
\hline
\end{tabular}




\begin{tabular}{llll}
\hline No. Sastra & \multicolumn{2}{c}{ Sejarah } & Keterkaitan \\
\hline & Gunung Ciung, Pasarean & \\
& Gede, Sumedang. & \\
\hline
\end{tabular}

\section{PENUTUP}

Pangeran Kornel merupakan tokoh bupati yang sangat berpengaruh di wilayah Kabupaten Sumedang, sehingga namanya bukan saja terukir dalam catatan sejarah, tetapi juga diabadikan dalam karya sastra. Hal tersebut terjadi di samping untuk memberikan rasa hormat atas kebesaran namanya, juga untuk mengenang dan memperkenalkan jiwa patriotismenya kepada generasi berikutnya. Dalam perspektif sastra, Pangeran Kornel pernah diceritakan dalam bentuk novel, yang berjudul Pangéran Kornél karya R. Memed Sastrahadiprawira dan dalam sajak "Cadas Pangéran" karya Yus Rusyana. Novel tersebut memiliki struktur yang lengkap, mulai dari tema, fakta cerita, dan sarana sastranya. Selanjutnya dalam perspektif sejarah, Pangeran Kornel dibuktikan dengan fakta yang tertera dalam prasasti yang ada di Jalan Cadas Pangeran dan juga dalam surat pernyataan dari Belanda yang memuji keberhasilan Pangeran Kornel, yang telah memimpin Kabupaten Sumedang menjadi wilayah yang maju dari segi kewilayahan, ekonomi, dan juga pemerintahan. Keterkaitan tokoh Pangeran Kornel dalam perspektif sastra dan sejarah dapat dilihat dari hubungan ceritanya yang memiliki kesamaan. Walaupun ditemukan adanya perbedaan, tetapi secara umum cerita tersebut saling berhubungan dan saling memengaruhi, yang membedakannya hanya dari segi penceritaannya saja, bahwa dalam sastra telah ada campur tangan pengarang berupa daya imajinasi dan unsur fiksionalitas, sedangkan dalam sejarah hanya bersandar pada fakta-fakta yang ada.

\section{DAFTAR PUSTAKA}

Danadibrata. (2015). Kamus Basa Sunda. Bandung: Kiblat Buku Utama.

Darajat, D., dkk. (2020). "Karakteristik Kepemimpinan Sunda dalam Novel Sejarah Mantri Jero Karya R. Memed Sastrahadiprawira". Lokabasa, Vol. 11, No. 1. Diakses: https://ejournal.upi.edu/index.php/lokabasa/article/view/25162.

Goleman, D. (2006). Emotional Intelegence: Mengapa EQ Lebih Penting daripada IQ. Jakarta: Gramedia Pustaka Utama.

Handayani, R., dkk. (2019). "Rekam Jejak Pangeran Aria Soeria Atmadja (Bupati Sumedang Tahun 1883-1919)". Factum, Vol. 8, No. 1, April 2019. Diakses: https://ejournal. upi.edu/index.php/factum/article/view/20120.

Iskandarwassid. (2019). Kamus Istilah Sastra Sunda. Bandung: Geger Sunten.

Isnendes, R., dan Firmansyah, U. (2013). "Masyarakat Sunda dalam Sastra: Komparasi Moralitas dan Kepribadian". Lokabasa, Vol. 4, No. 1, April 2013. Diakses: https:// ejournal.upi.edu/index.php/lokabasa/article/view/3128/2149.

Kurnia, G. D., \& Zahro, A. (2021). "Kecerdasan Emosional Tokoh Perempuan Muslimah dalam Novel Assalamualaikum Beijing Karya Asma Nadia". Diglosia: Jurnal Kajian Bahasa, Sastra, dan Pengajarannya, 4 (1), 37-48. https://doi.org/10.30872/ diglosia.v4i1.89.

Kosmajadi, E. (1994). Sajarah Sumedang. Sumedang: Mitra Pustaka.

Lubis, N. H., dkk. (2008). Sejarah Sumedang dari Masa ke Masa. Sumedang: Dinas Pariwisata dan Kebudayaan Kabupaten Sumedang bekerja sama dengan Pusat Kebudayaan Sunda Fakultas Sastra Universitas Padjadjaran. 
Mandela, W. (2015). "Pendidikan Karakter dan Budaya Bangsa dalam Dongeng Gunung Tampomas dan Cadas Pangeran (dalam Konteks Pembelajaran Bahasa Indonesia Kelas V SD)". Jurnal Cakrawala Pendas, Vol. 1, No. 2, Juli 2015. Diakses: https://www.researchgate.net/publication/336276744.

Marihandono, D. (2008). "Mendekonstruksi Mitos Pembangunan Jalan Raya Cadas Pangeran 1808: Komparasi Sejarah dan Tradisi Lisan". Makalah disajikan pada acara Peringatan 70 Tahun Prof. Dr. RZ Leirissa, yang bertemakan "Refleksi Keilmuan Prof. Dr. RZ Leirissa", diselenggarakan oleh Departemen Sejarah Fakultas Ilmu Pengetahuan Budaya Universitas Indonesia, tanggal 29 dan 30 April 2008. Diakses: https://adoc.tips/download/ mendekonstruksimitos-pembangunan-jalan-raya-cadas-pa ngeran-.html.

Nurgiyantoro. (2013). Teori Pengkajian Fiksi. Yogyakarta: Gadjah Mada University Press.

Nurlaela. (2019). Pengaruh Kisah Cadas Pangeran terhadap Perubahan Pola Berpikir Pada Siswa Kelas XI IPS 4 di SMAN 1 Sumedang Semester Genap Tahun Ajaran 2018/2019. (Skripsi). Pendidikan Sejarah, FKIP Universitas Siliwangi. Diakses: http://repositori.unsil.ac.id/511/.

Prasasti Pembuatan Jalan Raya Cadas Pangeran. Sumedang.

Sastrahadiprawira, R. M. (2014). Pangéran Kornél. Bandung: Kiblat Buku Utama.

Sjamsuddin, H. (2007). Metodologi Sejarah. Yogyakarta: Ombak.

Stanton, R. (2012). Teori Fiksi Robert Stanton. Yogyakarta: Pustaka Pelajar.

Sukur, A., dan Soemawilaga, F. (2021). "Cerita Pangeran Kornel". Hasil Wawancara Pribadi: 17 Februari 2021, Museum Prabu Geusan Ulun Sumedang.

Suryaningrat, B. (1983). Sejarah Kabupatian I Bhumi Sumedang 1550-1950.

Wangsapurwacaraka, W. (1994). Rucatan Budaya Bumi Sumedang. Sumedang: Departemen Pendidikan dan Kebudayaan Kab. Sumedang kerja sama dengan Sanggar Getamas-Lingga Mustika dan diterbitkan oleh Hanjuang Hegar. 